\title{
Relationship between EGFR expression, copy number and mutation in lung adenocarcinomas
}

\author{
Zhiyong Liang, Jing Zhang, Xuan Zeng, Jie Gao, Shafei Wu, Tonghua Liu*
}

\begin{abstract}
Background: This study was designed to investigate EGFR protein expression, EGFR copy number and EGFR mutations in lung adenocarcinomas, to explore the relationship of the three markers.

Methods: EGFR status was analyzed in surgically resected lung adenocarcinoma samples from 133 Chinese patients by three methods: protein expression $(n=133)$ by standardized immunohistochemistry $(I H C)$, gene copy number ( $n=133$ ) by fluorescence in situ hybridization $(\mathrm{FISH})$, and mutation analysis using the Scorpion amplification refractory mutation system (ARMS) $(n=133)$.

Results: The results showed that $68.4 \%$ of the samples were positive by $\mathrm{IHC}, 42.1 \%$ were positive by $\mathrm{FISH}$, and 63.9\% contained activating kinase domain mutations. EGFR mutations were more frequent in non-smoking patients $(p=0.008)$, and EGFR mutations were associated with EGFR FISH positivity $(p<0.0001)$. When using $10 \%$ positivity and $2+$ as cutoffs, EGFR protein expression was significantly correlated with EGFR FISH positivity $(p=0.012)$ and EGFR mutations ( $p=0.008)$ after Bonferroni correction.

Conclusion: EGFR protein expression, EGFR copy number and EGFR mutations were closely related to each other. Standard methods and interpretation criteria need to be established.
\end{abstract}

\section{Background}

Lung cancer is one of the leading causes of cancer-related deaths in the world. Recently, EGFR-targeted therapy has proven effective in treating non-small cell lung cancer (NSCLC). The epidermal growth factor receptor (EGFR, HER-1/ErbB1) is a receptor tyrosine kinase (TK) of the ErbB family, which consists of four closely related receptors: HER-1/ErbB1, HER-2/neu/ErbB2, HER-3/ErbB3, and HER-4/ErbB4. The agents approved for the treatment of NSCLC are monoclonal antibodies (MoAbs) directed against EGFR and small-molecule TK inhibitors (TKIs). Given the low response rate, the identification of the patients who are most likely to derive clinical benefit from EGFR-targeted therapy is important [1-6].

Increased EGFR gene copy number as detected by FISH was strongly correlated with response, progressionfree survival (PFS) and overall survival (OS) after treatment with EGFR TK inhibitors (TKI) in previous studies. These results suggested that a high EGFR gene copy number is a strong indicator of TKI sensitivity $[7,8]$.

\footnotetext{
* Correspondence: liuth_pumch@yahoo.com.cn

Department of Pathology, Peking Union Medical College Hospital, Chinese Academy of Medical Science, Beijng 100730, China
}

Several clinical features were found to be associated with increased response rates to EGFR TKIs, including Asian ethnicity, non-smoking history, female gender and adenocarcinoma histology. EGFR mutations were reported to be associated with these clinical features in several clinical trials [9]. Mutations in the tyrosine kinase domain of EGFR were reported in the majority of tumors with dramatic responses to EGFR-targeted therapies, and an activating mutation of the EGFR tyrosine kinase domains was shown to be associated with EGFR TKI sensitivity [10-12]. EGFR gene mutations predicted increased overall survival of TKI-treated patients in some studies, but failed to indicate a survival benefit in other series of studies [10-14]. In recent studies, an association between EGFR mutations and high EGFR copy number was demonstrated $[7,15]$.

It is still not clear whether EGFR protein expression could be a predictor of successful EGFR-targeted therapy. Due to the different antibodies, protocols and interpretation criteria used, as well as the different patient populations analyzed, EGFR protein expression in NSCLC has been variably reported. The association between EGFR protein expression as detected by immunohistochemistry 
(IHC) and the response to EGFR TKIs is controversial. The reported relationship between EGFR protein expression and EGFR copy number/EGFR mutation also varies in different studies $[16,17]$.

Multiple methodological approaches have been used, including mutational analysis, fluorescence in situ hybridization, and immunohistochemistry. Conflicting results reflect the lack of standardization of the methodology and interpretation. In this study, we used the standardized PharmDx (Dako) IHC kit to analyze EGFR expression. We also analyzed gene copy number by FISH using the most standard probes (Vysis), and the mutations were analyzed by the stable and sensitive Scorpion amplification refractory mutation system (ARMS). We attempted to explore the relationship between EGFR protein expression, EGFR copy number, and EGFR mutation.

\section{Methods \\ Patients}

All of the specimens were selected by two pathologists, only patients with primary lung adenocarcinoma were selected, intrapulmonary metastases and recurrent disease were not included in this study. None of the selected patients were previously treated with chemotherapy, radiation or anti-EGFR therapy. Only cases with available EGFR immunohistochemistry, mutational status, and EGFR FISH data were analyzed. Clinical information included gender, age, smoking status, tumor stage and lymph node metastasis status. One hundred and thirty-three Chinese patients with lung adenocarcinomas were selected from 886 lung cancer patients who underwent surgery at the Department of Surgery, Peking Union Medical College Hospital from Jan. 2000 to Jan. 2008. The patient group consisted of 62 males and 71 females, with an average age of 60 years. Cancer staging was classified according to the TNM cancer staging system of the American Joint Committee of Cancer (13): stage I, 69 cases; stage II, 17 cases; stage III, 33 cases and stage IV, 14 cases. The World Health Organization Classification of Tumors was used for histological classification and grading (18). The institutional review board at the Peking Union Medical College Hospital approved this study, and informed consent was obtained from all patients.

\section{Sample preparation}

All specimens were fixed in 10\% buffered formalin and embedded in paraffin according to standard procedures. All the tissues were fixed immediately after surgical resection, time from tissue acquisition to fixation was as short as possible; samples were fixed in 10\% neutral buffered formalin (avoiding Bouin or any fixative containing heavy metal ions) for 6-48 hours; samples were sliced properly after appropriate gross inspection and margins designation and placed in sufficient volume of $10 \%$ neutral buffered formalin.

Serial sections (4-5 $\mu \mathrm{m}$ thickness) placed on positively charged slides (MENZEL-GLASSER, GERMAN) were used for hematoxylin and eosin staining, immunohistochemistry, and FISH detection of EGFR.

\section{FISH analysis of EGFR copy number}

EGFR FISH analysis was carried out using the LSI EGFR SpectrumOrange/CEP 7 SpectrumGreen probe (Vysis, Abbott Laboratories) according to the manufacturer's protocol. Sections were incubated at $56^{\circ} \mathrm{C}$ overnight, deparaffinized by washing in CitriSolv (Fisher Scientific, Pittsburgh, PA), and dehydrated in $100 \%$ ethanol. After incubation in $2 \times$ saline sodium citrate buffer $(2 \times$ SSC, $\mathrm{pH} 7.0)$ at $75^{\circ} \mathrm{C}$ for $15-25$ minutes, sections were digested with proteinase $\mathrm{K}(0.25 \mathrm{mg} / \mathrm{mL}$ in $2 \times \mathrm{SSC} ; \mathrm{pH} 7.0)$ at $37^{\circ} \mathrm{C}$ for $15-25$ minutes, rinsed in $2 \times \mathrm{SSC}$ at room temperature for 5 minutes, and dehydrated in a series of increasing concentrations of ethanol $(70 \%, 85 \%$, and $100 \%$ ). The EGFR/CEP 7 probe set was applied to the selected area based on the presence of tumor foci on each slide, and the hybridization area was covered with a glass coverslip and sealed with nail polish. The slides were incubated at $80^{\circ} \mathrm{C}$ for $8-10$ minutes for co-denaturation of the chromosomal and probe DNA and were then hybridized at $37^{\circ} \mathrm{C}$ for $20-24$ hours. Post-hybridization washes were performed in $1.5 \mathrm{M}$ urea and $0.1 \times$ SSC $(\mathrm{pH} 7.0-7.5)$ at $45^{\circ} \mathrm{C}$ for 30 minutes, and in $2 \times \mathrm{SSC}$ for 2 minutes at room temperature. After the samples were dehydrated in ethanol as above, 4', 6'-diamidino-2phenylindole (DAPI) in phosphate-buffered saline and glycerol (Vysis) was applied for chromatin counterstaining. FISH analyses were performed independently by two authors who were blinded to the clinical characteristics of the patients and to all other molecular variables. For EGFR FISH analyses, 60 nuclei were scored for signals from both DNA probes using an Olympus BX51TRF microscope (Olympus, Japan) equipped with a triple-pass filter (DAPI/Green/Orange; Vysis) at a final magnification of $1000 \times$.

Chromosome 7 polysomy and monosomy were defined as the presence of $\geq$ three signals and one signal, respectively, in more than $20 \%$ of the tumor cells. EGFR gene status was classified into six categories according to the frequency of tumor cells with specific copy numbers of the EGFR gene and the chromosome 7 centromere as described elsewhere [7]: disomy ( $\leq 2$ copies in $\geq 90 \%$ of cells), low trisomy ( $\leq 2$ copies in $\geq 40 \%$ of cells, 3 copies in $10-40 \%$ of cells, and $\geq 4$ copies in $<10 \%$ of cells), high trisomy ( $\leq 2$ copies in $\geq 40 \%$ of cells, 3 copies in $\geq 40 \%$ of cells, and $\geq 4$ copies in $<10 \%$ of cells), low polysomy ( $\geq 4$ copies in $10-40 \%$ of cells), high polysomy 
( $\geq 4$ copies in $\geq 40 \%$ of cells), and gene amplification (a: presence of tight EGFR gene clusters ( $\geq 4$ spots) in $\geq 10 \%$ tumor cells;b: a ratio of the EGFR gene to chromosome 7 of $\geq 2$, c: $\geq 15$ copies of EGFR per cell in $\geq 10 \%$ of cells). Based on the EGFR gene status, patients were further classified into two groups: 1) EGFR FISH-negative or low gene copy (disomy, low trisomy, high trisomy, and low polysomy) and 2) EGFR FISH-positive or high gene copy (high polysomy and gene amplification)[18]. For each FISH preparation, known positive and negative cells were used as controls.

\section{Scorpion ARMS analysis of EGFR mutations}

The tumor specimens were fixed with $10 \%$ neutral buffered formalin and embedded in paraffin. Using a NucleoSpin tissue isolation kit (Machery-Nagel, Germany), DNA was extracted from tumor tissues derived by manual microdissection carried out to enrich tumor cells. EGFR mutations of exon 18-21 were detected using the DxS ARMS EGFR29 mutation test kit (DxS Limited, Manchester, UK). Twenty-nine of the most common somatic mutations of the EGFR gene can be detected by the kit.

\section{Immunohistochemical analysis of EGFR expression}

Immunohistochemistry for EGFR was performed using the EGFR pharmDx kit (DakoCytomation, Denmark) according to the manufacturer's instructions. Antibody binding was visualized using the EnVison detection kit (DakoCytomation, Denmark).

Immunohistochemical staining for EGFR was scored as follows: 0, no discernible staining or presence of background staining only; $1+$, equivocal discontinuous membrane staining; $2+$, unequivocal membrane staining with moderate intensity; and $3+$, strong and complete plasma membrane staining. More than $10 \%$ of the cells were required to meet the criteria for EGFR analysis. Samples with more than $10 \%$ of the tumor cells showing membranous (partial or complete) staining at the $2+$ and $3+$ staining levels were considered to be EGFR IHC-positive, and the highest score obtained among different areas of the same tumor was used as the final EGFR IHC result for that tumor. To determine which criteria were more suitable, two other evaluation criteria were used in this study. The first was that samples with more than $10 \%$ of tumor cells showing membranous (partial or complete) staining of any intensity were considered to be EGFR IHC-positive. The second criterion we used was the semiquantitation score defined by Capuzzo et al. [7], with the modification that we evaluated membranous staining and determined four levels of intensity $(0,1+, 2+$ and $3+)$ according to the instructions of the manufacturer (Dako). The IHC score was calculated by multiplying the staining intensity and the fraction of positive cells $(0-100 \%)$. The scores were 0-300 in different tumors, and scores of more than 100 were considered as indicative of EGFR IHC positivity $[19,20]$.

\section{Statistical analysis}

Statistical analyses were performed using Pearson's Chi-squared test or Fisher's exact test to determine significant clinicopathological differences between EGFR expression in positive and negative tumors, between EGFR FISH-positive and FISH-negative tumors, and between tumors with and without EGFR mutations. These tests were also used to determine the association between EGFR protein expression, EGFR FISH results, and EGFR mutations. Bonferroni correction was performed to adjust for multiple comparisons, differences with $\mathrm{P}<0.05 /$ comparison times were considered significant.

\section{Results}

\section{EGFR copy number in lung adenocarcinomas}

Eleven (8.3\%) of the 133 cases showed EGFR amplification, 45 cases $(33.8 \%)$ showed high polysomy, 38 cases (28.6\%) showed low polysomy, 1 (0.7\%) case showed high trisomy, 15 cases $(11.3 \%)$ showed low trisomy, and 23 cases (17.3\%) showed disomy. Fifty-six cases (42.1\%) showed FISH positivity according to the criteria of Capuzzo et al[7]. After Bonferroni correction for 5 comparisons, $\mathrm{P}<0.01$ were considered significant, EGFR FISH positivity was not associated with gender, smoking status, age, lymph node metastasis or tumor stage $(P \geq 0.01)$ (Table 1).

\section{EGFR mutations in lung adenocarcinomas}

Eighty-five (63.9\%) of the 133 cases showed EGFR mutations, which included 2 exon 18 G719X mutations (one also had an exon 20 S768I mutation), 39 exon 19 deletions, 4 exon 20 insertion mutations, 3 exon 20 S768I mutations (one also had an exon 18 G719X mutation), 35 exon 21 L858R mutations (one also had an exon 20 T790 M mutations), and 3 exon 21 L861Q mutation. After Bonferroni correction for 5 comparisons, $\mathrm{P}<0.01$ were considered significant, EGFR mutations were significantly associated with smoking status (non-smoking vs. smoking, $\mathrm{p}=0.008$ ), and were not associated with age, gender, lymph node metastasis or tumor stage $(p \geq 0.01)$ (Table 1).

\section{Association between EGFR copy number and EGFR mutations}

In our results, EGFR FISH positivity was significantly associated with EGFR mutations $(\mathrm{p}<0.001)$. Forty-five of the 56 (80.4\%) FISH-positive cases, which included 7 amplifications and 38 instances of high polysomy 
Table 1 Relationship between EGFR mutation, EGFR copy number and clinicopathological characteristics of lung adenocarcinoma

\begin{tabular}{|c|c|c|c|c|c|c|c|c|c|}
\hline & \multicolumn{2}{|c|}{$\mathrm{IHC}$} & \multirow[b]{2}{*}{$\begin{array}{c}P \\
\text { value }\end{array}$} & \multicolumn{2}{|c|}{ Mutation } & \multirow[b]{2}{*}{$\begin{array}{c}P \\
\text { value }\end{array}$} & \multicolumn{2}{|c|}{ FISH } & \multirow[b]{2}{*}{$\begin{array}{c}P \\
\text { value }\end{array}$} \\
\hline & + & - & & + & - & & + & - & \\
\hline \multicolumn{10}{|l|}{ Gender } \\
\hline Male & 41 & 21 & 0.595 & 34 & 28 & 0.042 & 27 & 35 & 0.753 \\
\hline Female & 50 & 21 & & 51 & 20 & & 29 & 42 & \\
\hline \multicolumn{10}{|l|}{ Age } \\
\hline$>60$ & 50 & 23 & 0.984 & 51 & 22 & 0.115 & 30 & 43 & 0.795 \\
\hline$<60$ & 41 & 19 & & 34 & 26 & & 26 & 34 & \\
\hline \multicolumn{10}{|l|}{ Smoking status } \\
\hline Positive & 61 & 25 & 0.400 & 62 & 24 & 0.008 & 36 & 20 & 0.938 \\
\hline Negative & 30 & 17 & & 23 & 24 & & 50 & 27 & \\
\hline \multicolumn{10}{|l|}{$\begin{array}{l}\text { Lymph node } \\
\text { metastasis }\end{array}$} \\
\hline Positive & 59 & 28 & 0.836 & 58 & 29 & 0.363 & 33 & 54 & 0.180 \\
\hline Negative & 32 & 14 & & 27 & 19 & & 23 & 23 & \\
\hline \multicolumn{10}{|l|}{ Stage } \\
\hline 1 & 47 & 22 & 0.937 & 45 & 24 & 0.744 & 22 & 47 & 0.021 \\
\hline$\|$ & 15 & 2 & & 12 & 5 & & 11 & 6 & \\
\hline III & 21 & 12 & & 19 & 14 & & 14 & 19 & \\
\hline IV & 8 & 6 & & 9 & 5 & & 8 & 6 & \\
\hline
\end{tabular}

After Bonferroni correction, $\mathrm{P}<0.01$ was considered as significant, only the association between EGFR mutation and smoking status was statistically significant.

showed EGFR mutations. Forty of the 77 (52\%) FISHnegative cases, which included 23 low polysomy cases, 10 low trisomy cases, and 7 disomy cases showed EGFR mutations. There were no significant differences in the EGFR FISH-positive rate among different mutation patterns $(\mathrm{p} \geq 0.05)$ (Table 2).

\section{EGFR protein expression in lung adenocarcinomas}

Sixty-one (45.8\%) of the 133 cases showed EGFR expression levels corresponding to $3+, 30(22.6 \%)$ cases showed EGFR levels of $2+$, and 23 (17.3\%) cases showed EGFR levels of $1+$; the remaining 19 (14.3\%) cases showed level 0 staining ( $\mathrm{n}=133$ lung adenocarcinoma samples).

\section{Correlation of EGFR expression, EGFR copy number and EGFR mutations}

According to the criteria that samples with more than $10 \%$ of tumor cells showing membranous staining of any

Table 2 Relationship between EGFR copy number and mutation

\begin{tabular}{lll}
\hline Mutation & \multicolumn{2}{c}{ FISH } \\
\cline { 2 - 3 } & Positive & Negative \\
\hline Positive & 45 & 40 \\
negative & 11 & 37 \\
\hline P value & & $P<0.0001$ \\
\hline
\end{tabular}

intensity should be considered as EGFR IHC-positive, 114 cases were IHC-positive and 19 cases were IHCnegative. After Bonferroni correction for 2 comparisons, $\mathrm{P}<0.025$ were considered significant, the FISH-positive rate was not significantly different between IHC-positive and IHC-negative groups $(\mathrm{p}=0.132)$, and the mutation rate was not significantly different between the IHC-positive and IHC-negative groups $(\mathrm{p}=0.105)$ (Table 3$)$.

According to the criterion that samples with more than $10 \%$ of tumor cells showing membranous staining at levels $2+$ and 3+ should be considered to be EGFR IHC-positive, 91 cases were IHC-positive and 42 cases were negative. After Bonferroni correction for 2 comparisons, $\mathrm{P}<0.025$ were considered significant, the FISH-positive rate was significantly higher in the IHC-positive group than in the IHC-negative group $(p=0.012)$, and the mutation rate was significantly higher in the IHC-positive group than in the IHC-negative group ( $\mathrm{p}=0.008)$ (Figure 1, Table 3 ). But the patients positive for the three EGFR markers did not completely overlap; some of FISH-positive and mutant samples was IHC-negative (Figure 2).

According to semiquantitation criteria, 88 cases were IHC-positive and 46 cases were negative. After Bonferroni correction for 2 comparisons, $\mathrm{P}<0.025$ were considered significant, the mutation rate was significantly higher in the IHC-positive group than in the IHC-negative group $(\mathrm{p}=0.008)$, the FISH-positive rate was higher in the IHC-positive group than in the IHC-negative group (approached significance, $\mathrm{p}=0.027$ ) (Table 3).

Similar results were obtained using either of the latter two criteria. The results indicated that EGFR IHC positivity was significantly correlated with EGFR mutations and EGFR FISH positivity (the association between the third EGFR IHC criteria and EGFR FISH positivity was close to statistically significant). Due to its easier application, we used the criterion that samples with more than $10 \%$ of tumor cells showing membranous staining at levels $2+$ and 3+ should be considered to be EGFR IHC-positive in our following analysis. There were no significant differences in the rates of IHC positivity in patients of different age, gender, smoking status, lymph node metastasis and stage ( $p \geq 0.01$ after Bonferroni correction).

\section{Discussion}

Due to the potential high benefit of EGFR TKI therapy for treatment of lung adenocarcinomas, several clinically trials have focused on lung adenocarcinomas. Because a low proportion $(<30 \%)$ of patients respond to EGFR TKI, patient selection is very important for initiating EGFR TKI therapy [1-6]. EGFR gene copy number determined by FISH, protein expression determined by IHC and EGFR tyrosine kinase mutations are all potential markers to be used as selection criteria in EGFR-targeted therapy. Multiple methodological approaches have been used in 
Table 3 Relationship between EGFR protein expression and EGFR copy number, and mutation

\begin{tabular}{|c|c|c|c|c|c|c|}
\hline \multirow[t]{2}{*}{ IHC criteria } & \multicolumn{2}{|c|}{ Mutation } & \multirow[b]{2}{*}{$P$ value } & \multicolumn{2}{|c|}{ FISH } & \multirow[b]{2}{*}{$P$ value } \\
\hline & positive & negative & & positive & negative & \\
\hline \multicolumn{7}{|l|}{ First criteria } \\
\hline Positive ( $>10 \%$ tumor cells, ++ and +++$)$ & 65 & 26 & 0.008 & 45 & 46 & 0.012 \\
\hline Negative & 20 & 22 & & 11 & 31 & \\
\hline \multicolumn{7}{|l|}{ Second criteria } \\
\hline Positive (>10\% tumor cells, any intensity) & 76 & 38 & 0.105 & 51 & 63 & 0.132 \\
\hline Negative & 9 & 10 & & 5 & 14 & \\
\hline Third criteria Positive (H Score $\geq 100$ ) & 62 & 24 & 0.008 & 42 & 44 & 0.027 \\
\hline Negative(H Score < 100) & 23 & 24 & & 14 & 33 & \\
\hline
\end{tabular}

After Bonferroni correction, $\mathrm{P}<0.025$ was considered as significant. For using the first IHC criteria, IHC were significantly associated with mutation and FISH. For using the second IHC criteria, no significant association was found between IHC and mutation or FISH. For using the third IHC criteria, IHC was significantly associated with mutation, approached significant associated with $\mathrm{FISH}(\mathrm{P}=0.027$, close to 0.025$)$

the detection of EGFR mutations, EGFR copy number and EGFR protein expression, but the results were contradictory. It is important to standardize the approach and decide which assays are best to predict patient responses to targeted therapies.

It was demonstrated that mutations in exons 18 to 21 of the tyrosine kinase domain of EGFR were correlated with a high response to EGFR TKIs in lung adenocarcinomas. In previous studies, EGFR mutations were reported in about $22 \%$ to $67 \%, 10 \%$ to $24 \%$, and $3 \%$ to 25\% of Asian population, Southern European, and American populations with lung adenocarcinomas [10,12,14,15,21-26]. In this study, $63.9 \%(85 / 133)$ of patients with lung adenocarcinomas had EGFR mutations. The higher frequency of mutations can most likely be attributed to the sampling from a Chinese population and the sensitive Scorpion ARMS method used. Although direct sequencing is still the gold standard method for mutation screening, many more sensitive methods have been developed, and Scorpion ARMS has been used in several clinical trials. Scorpion ARMS can detect a lower proportion of mutant alleles than direct sequencing; we demonstrated that Scorpion ARMS was more sensitive than direct sequencing in detecting EGFR mutations in lung carcinomas in our previous study [27]. Others reported that some cases with mutations are missed by direct sequencing of clinical tumor samples; however, these cases could be detected by more sensitive techniques. In this study, about $90 \%(74 / 85)$ of EGFR mutations consisted of deletions in exon 19 and L858R mutations in exon 21, and EGFR mutations were significantly associated with smoking status, consistent with previous reports, but not associated with gender, this may be caused by small sample size in our group. Other less common mutations were also identified in our study, including one T790 M mutation that has been demonstrated to result in EGFR TKI resistance in clinical trials.
High EGFR gene copy number/amplification has been reported in $7 \%$ to $45 \%$ of lung carcinomas. This large range may be due to variations in techniques, criteria for determining positivity, and interobserver variability $[7,8,15,20,28]$. In our study, standard Vysis EGFR FISH probes and the Capuzzo et al. criteria were used to evaluate EGFR copy number in lung adenocarcinomas. We found that $42.1 \%(56 / 133)$ of lung adenocarcinomas showed EGFR FISH positivity, and that EGFR FISH positivity was more frequent in late stages than in early stages of lung adenocarcinomas (although no statistically significant difference showed after Bonferroni correction, but there was trend show difference, probably due to the reason of low volume samples.). Awaya et al. [29] detected FISH only in the invasive components of adenocarcinomas, and Kim et al. [30] frequently observed increased EGFR in advanced stages of lung adenocarcinoma. This may be consistent with previous reports of poor prognosis of lung carcinomas with higher EGFR copy numbers. Our studies and several others from Western and American populations demonstrated that high EGFR copy numbers were significantly associated with EGFR mutations, contrary to the result published by Sasaki et al. [31] in a study of Japanese patients in which no correlation was found between EGFR copy number and EGFR mutation. There may be reasons other than ethnicity for this discrepancy. The relationship between high EGFR copy number and EGFR mutation is complex. Recent studies report a mutant allele specific imbalance of oncogenes in tumor cells harboring gene mutation; copy number gain of EGFR usually occurred in the cells with an EGFR mutation[32]. Previous studies reported that EGFR mutant alleles were amplified selectively, resulting in a high EGFR copy number[15]. Yatabe, et al. [33] reported that EGFR amplification was acquired during invasive growth of lung adenocarcinoma with EGFR mutations. 


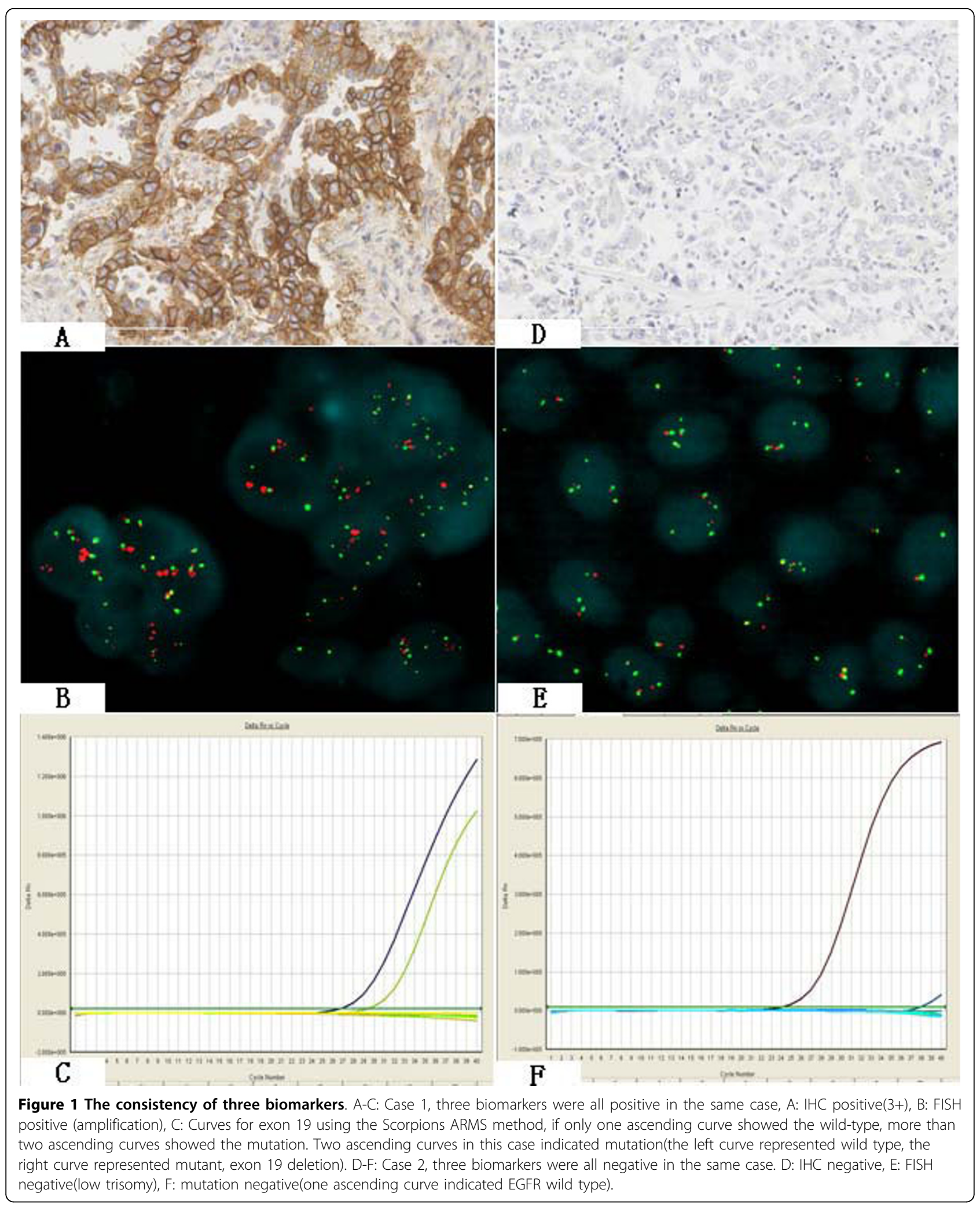




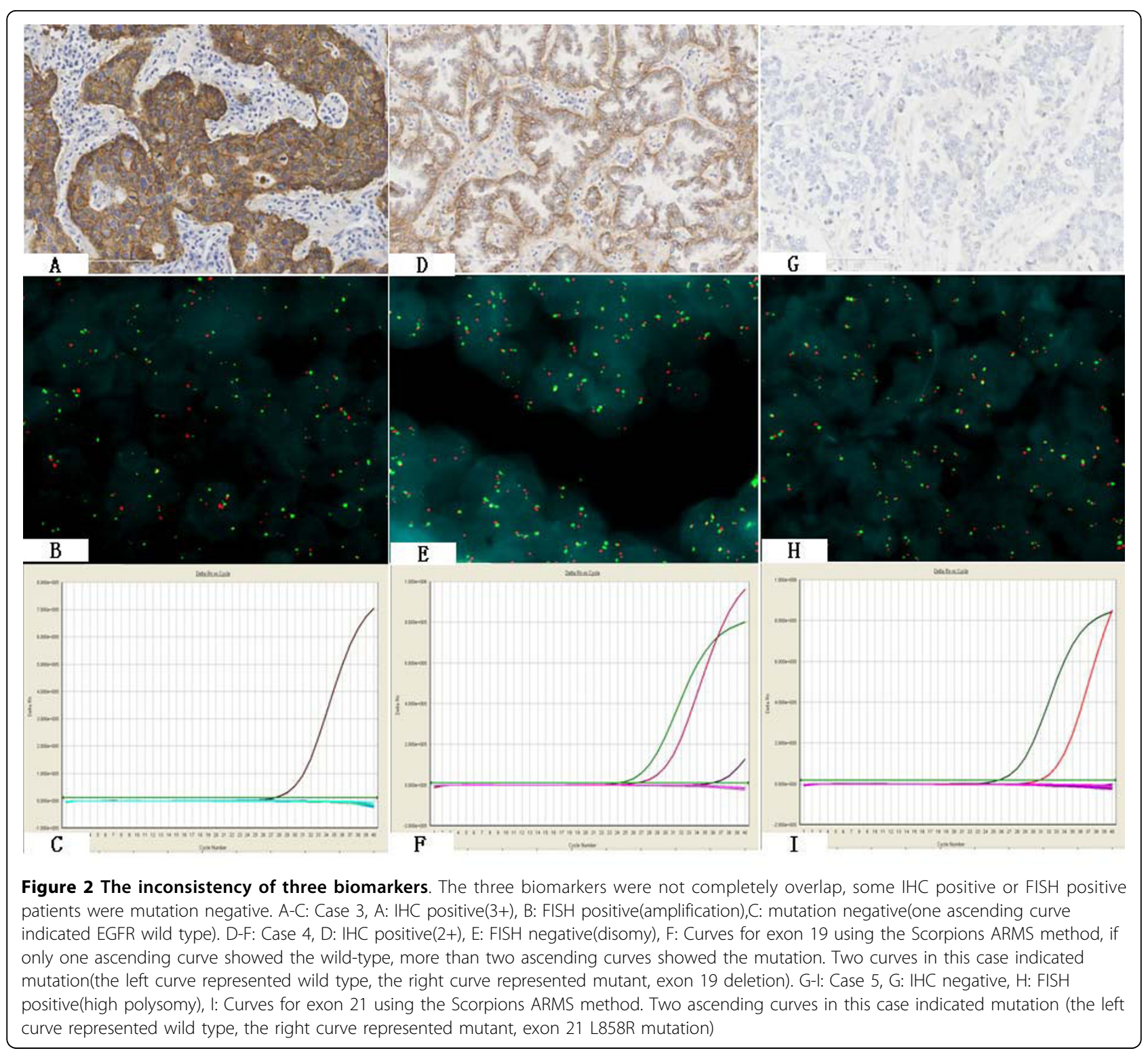

Soh, et al. [34] have found that an increase in EGFR copy number was a relatively late event in NSCLC pathogenesis and that EGFR mutation preceded EGFR amplification. These may partially explain the association between high EGFR copy number and EGFR mutation, the precise mechanism needs to be clarified in future studies.

EGFR expression has been variably reported in 27 to $83 \%$ of NSCLC cases, and there are conflicting results on the prognostic implication of EGFR expression in NSCLC.

Different EGFR IHC results highly depend on the type of antibody, procedure protocols, selection of scoring methods, and cut-offs implemented. A standard method has not been adopted, and the significance of EGFR protein expression in NSCLC remains contradictory [35-39]. To select the best evaluation standard for EGFR IHC, we compared three different criteria in our study. When we used the criterion that samples with more than $10 \%$ of tumor cells showing membranous staining of levels of $2+$ and $3+$ should be considered to be EGFR IHC-positive, the results were statistically similar to those obtained using the Capuzzo et al[7] criteria. EGFR protein expression was significantly associated with EGFR copy number and EGFR mutations, and this was consistent with results from most of the previous studies [40]. In contrast, if we used $10 \%$ positivity regardless of intensity as a cut-off, the results were quite different, and no correlation was found between EGFR protein expression, EGFR copy number and EGFR gene mutation. 
These results suggest that the establishment of standard methods and interpretation of standards is very important in clinical practice.

We prefer to use $10 \%$ positivity and an intensity level of $2+$ as cut-off criteria. In our study, $68.4 \%$ (91/133) of lung adenocarcinomas were EGFR IHC-positive according to our interpreting criteria. EGFR protein expression was significantly associated with EGFR copy number and EGFR mutation, but not associated with gender, age, smoking status, lymph node metastasis or stage.

The results suggest that EGFR protein expression may predict EGFR gene status (including copy number and mutation) to some extent. However, the patients positive for the three EGFR markers did not completely overlap; a proportion of FISH-positive and mutant samples was IHC-negative. Thus, the mechanism needs to be clarified in the future.

\section{Conclusion}

EGFR protein expression, EGFR copy number and mutations were investigated in this study. Our results revealed that the deletion in exon 19 and the L858R point mutation were the major EGFR mutations in lung adenocarcinomas, and EGFR mutations were significantly associated with smoking status. Furthermore, EGFR copy number was significantly associated with EGFR mutation, and EGFR protein expression was significantly correlated with EGFR copy number and mutation. Standard methods and criteria should be established for patient selection for EGFR target therapy. Further studies will be required to determine whether EGFR copy number and EGFR protein expression analysis are suitable for individualized EGFR targeted therapy.

\section{Acknowledgements}

This study was supported by a grant 2006BAI02A14 of 11th Five-Year Plan scientific and technological support from the Ministry of Science and Technology of the Peoples' Republic of China.

\section{Authors' contributions \\ ZYL designed the experiment and drafted the manuscript, JZ participated in specimen collection and data analysis $X Z$ participated in experiment design and performed FISH analysis, JG performed immunohistochemistry staining and mutation tests, SW carried out FISH analysis, THL conceived of the study, and participated in its design and coordination. All authors read and approved the final manuscript.}

\section{Competing interests}

The authors declare that they have no competing interests.

Received: 24 December 2009 Accepted: 19 July 2010 Published: 19 July 2010

\section{References}

1. Uramoto H, Mitsudomi T: Which biomarker predicts benefit from EGFRTKI treatment for patients with lung cancer. Br J Cancer 2007, 96:857-863.

2. Kris MG, Natale RB, Herbst RS, Lynch TJ Jr, Prager D, Belani CP, Schiller JH, Kelly K, Spiridonidis H, Sandler A, Albain KS, Cella D, Wolf MK, Averbuch SD, Ochs JJ, Kay AC: Efficacy of gefitinib, an inhibitor of the epidermal growth factor receptor tyrosine kinase, in symptomatic patients with non-small cell lung cancer: a randomized trial. JAMA 2003, 290:2149-2158.

3. Fukuoka M, Yano S, Giaccone G, Tamura T, Nakagawa K, Douillard JY, Nishiwaki Y, Vansteenkiste J, Kudoh S, Rischin D, Eek R, Horai T, Noda K, Takata I, Smit E, Averbuch S, Macleod A, Feyereislova A, Dong RP, Baselga J: Multi-institutional randomized phase II trial of gefitinib for previously treated patients with advanced non-small-cell lung cancer (The IDEAL 1 Trial). J Clin Oncol 2003, 21:2237-2246.

4. Shepherd FA, Rodrigues Pereira J, Ciuleanu T, Tan EH, Hirsh V, Thongprasert S, Campos D, Maoleekoonpiroj S, Smylie M, Martins R, van Kooten M, Dediu M, Findlay B, Tu D, Johnston D, Bezjak A, Clark G, Santabarbara P, Seymour L: National Cancer Institute of Canada Clinical Trials Group: Erlotinib in previously treated non-small-cell lung cancer. $N$ Engl J Med 2005, 353:123-132.

5. Schwab R, Pinter F, Moldavy J, Papay J, Strausz J, Kopper L, Keri G, Pap A, Petak I, Oreskovich K, Mangel L: Amplification and mutation of the epidermal growth factor receptor in metastatic lung cancer with remission from gefitinib. J Clin Oncol 2005, 23:7736-7738.

6. Thatcher N, Chang A, Parikh P, Rodrigues Pereira J, Ciuleanu T, von Pawel J, Thongprasert S, Tan EH, Pemberton K, Archer V, Carroll K: Gefitinib plus best supportive care in previously treated patients with refractory advanced non-small-cell lung cancer: results from a randomised, placebo-controlled, multicentre study (Iressa Survival Evaluation in Lung Cancer). Lancet 2005, 366:1527-1537.

7. Cappuzzo F, Hirsch FR, Rossi E, Bartolini S, Ceresoli GL, Bemis L, Haney J, Witta S, Danenberg K, Domenichini I, Ludovini V, Magrini E, Gregorc V, Doglioni C, Sidoni A, Tonato M, Franklin WA, Crino L, Bunn PA Jr, VarellaGarcia M: Epidermal growth factor receptor gene and protein and gefitinib sensitivity in non-small-cell lung cancer. J Natl Cancer Inst 2005, 97:643-655.

8. Hirsch FR, Varella-Garcia M, McCoy J, West H, Xavier AC, Gumerlock P, Bunn PA Jr, Franklin WA, Crowley J, Gandara DR, Southwest Oncology: Increased epidermal growth factor receptor gene copy number detected by fluorescence in situ hybridization is associated with increased sensitivity to gefitinib in patients with bronchioloalveolar carcinoma subtypes. A Southwest Oncology Group study. J Clin Oncol 2005, 23:6838-6845.

9. Hirsch FR, Varella-Garcia M, Cappuzzo F, McCoy J, Bemis L, Xavier AC, Dziadziuszko R, Gumerlock P, Chansky K, West H, Gazdar AF, Crino L, Gandara DR, Franklin WA, Bunn PA Jr: Combination of EGFR gene copy number and protein expression predicts outcome for advanced nonsmall-cell lung cancer patients treated with gefitinib. Ann Oncol 2007, 18(4):752-60.

10. Pao W, Miller V, Zakowski M, Doherty J, Politi K, Sarkaria I, Singh B, Heelan R, Rusch V, Fulton L, Mardis E, Kupfer D, Wilson R, Kris M, Varmus H: EGF receptor gene mutations are common in lung cancer from "neversmokers" and are associated with sensitivity of tumor to gefitinib and erlotinib. Proc Natl Acad Sci USA 2004, 101:13306-11.

11. Lynch TJ, Bell DW, Sordella R, Gurubhagavatula S, Okimoto RA, Brannigan BW, Harris PL, Haserlat SM, Supko JG, Haluska FG, Louis DN, Christiani DC, Settleman J, Haber DA: Activating mutations in the epidermal growth factor receptor underlying responsiveness of nonsmall-cell lung cancer to gefitinib. N Engl J Med 2004, 350:2129-39.

12. Paez JG, Jänne PA, Lee JC, Tracy S, Greulich H, Gabriel S, Herman P, Kaye FJ, Lindeman N, Boggon TJ, Naoki K, Sasaki H, Fujii Y, Eck MJ, Sellers WR, Johnson BE, Meyerson M: EGFR mutations in lung cancer: correlation with clinical response to gefitinib therapy. Science 2004, 304:1497-500.

13. Lynch TJ, Bell DW, Sordella R, Gurubhagavatula S, Okimoto RA, Brannigan BW, Harris PL, Haserlat SM, Supko JG, Haluska FG, Louis DN, Christiani DC, Settleman J, Haber DA: Activating mutations in the epidermal growth factor receptor underlying responsiveness of nonsmall-cell lung cancer to gefitinib. N Engl J Med 2004, 350:2129-2139.

14. Han SW, Kim TY, Hwang PG, Jeong S, Kim J, Choi IS, Oh DY, Kim JH, Kim DW, Chung DH, Im SA, Kim YT, Lee JS, Heo DS, Bang YJ, Kim NK: Predictive and prognostic impact of epidermal growth factor receptor mutation in non-small-cell lung cancer patients treated with gefitinib. Clin Oncol 2005, 23:2493-2501.

15. Takano T, Ohe $Y$, Sakamoto H, Tsuta K, Matsuno Y, Tateishi U, Yamamoto S, Nokihara H, Yamamoto N, Sekine I, Kunitoh H, Shibata T, Sakiyama T, Yoshida T, Tamura T: Epidermal growth factor receptor gene mutations and increased gene copy numbers predict gefitinib sensitivity in 
patients with recurrent non-small-cell lung cancer. J Clin Oncol 2005, 23:6829-37.

16. Dacic S: EGFR assays in lung cancer. Adv Anat Pathol 2008, 15(4):241-7.

17. Eberhard DA, Giaccone G, Johnson BE, Non-Small-Cell Lung Cancer Working: Biomarkers of response to epidermal growth factor receptor inhibitors in Non-Small-Cell Lung Cancer Working Group: standardization for use in the clinical trial setting. $J$ Clin Oncol 2008 26(6):983-94

18. Varella-Garcia M, Diebold J, Eberhard DA, Geenen K, Hirschmann A, Kockx M, Nagelmeier I, Rüschoff J, Schmitt M, Arbogast S, Cappuzzo F: EGFR fluorescence in situ hybridisation assay: guidelines for application to non-small-cell lung cancer. J Clin Pathol 2009, 62(11):970-7.

19. Pinter F, Papay J, Almasi A, Sapi Z, Szabo E, Kanya M, Tamasi A, Jori B, Varkondi E, Moldvay J, Szondy K, Keri G, Dominici M, Conte P, Eckhardt S, Kopper L, Schwab R, Petak I: Epidermal Growth Factor Receptor (EGFR) High Gene Copy Number and Activating Mutations in Lung Adenocarcinomas Are Not Consistently Accompanied by Positivity for EGFR Protein by Standard Immunohistochemistry. Journal of Molecular Diagnostics 2008, 10(3):160-168.

20. Dacic S, Flanagan M, Cieply K, Ramalingam S, Luketich J, Belani C, Yousem SA: Significance of EGFR protein expression and gene amplification in non-small cell lung carcinoma. Am J Clin Pathol 2006, 125:860-865.

21. Cortes-Funes H, Gomez C, Rosell R, Valero P, Garcia-Giron C, Velasco A, Izquierdo A, Diz P, Camps C, Castellanos D, Alberola V, Cardenal F, Gonzalez-Larriba JL, Vieitez JM, Maeztu I, Sanchez JJ, Queralt C, Mayo C, Mendez P, Moran T, Taron M: Epidermal growth factor receptor activating mutations in Spanish gefitinib-treated non-small-cell lung cancer patients. Ann Oncol 2005, 16:1081-1086.

22. Mitsudomi T, Kosaka T, Endoh H, Horio Y, Hida T, Mori S, Hatooka S, Shinoda M, Takahashi T, Yatabe Y: Mutations of the epidermal growth factor receptor gene predict prolonged survival after gefitinib treatment in patients with non-small-cell lung cancer with postoperative recurrence. J Clin Oncol 2005, 23:2513-2520.

23. Chou TY, Chiu CH, Li LH, Hsiao CY, Tzen CY, Chang KT, Chen YM, Perng RP, Tsai SF, Tsai CM: Mutation in the tyrosine kinase domain of epidermal growth factor receptor is a predictive and prognostic factor for gefitinib treatment in patients with non-small cell lung cancer. Clin Cancer Res 2005, 11:3750-3757.

24. Tokumo M, Toyooka S, Kiura K, Shigematsu H, Tomii K, Aoe M, Ichimura K, Tsuda T, Yano M, Tsukuda K, Tabata M, Ueoka H, Tanimoto M, Date H, Gazdar AF, Shimizu N: The relationship between epidermal growth factor receptor mutations and clinicopathologic features in non-small cell lung cancers. Clin Cancer Res 2005, 11:1167-1173.

25. Shigematsu H, Lin L, Takahashi T, Nomura M, Suzuki M, Wistuba Il, Fong KM, Lee H, Toyooka S, Shimizu N, Fujisawa T, Feng Z, Roth JA, Herz J, Minna JD, Gazdar AF: Clinical and biological features associated with epidermal growth factor receptor gene mutations in lung cancers. J Natl Cancer Inst 2005, 97:339-346.

26. Marchetti A, Martella C, Felicioni L, Barassi F, Salvatore S, Chella A, Camplese PP, larussi T, Mucilli F, Mezzetti A, Cuccurullo F, Sacco R, Buttitta F: EGFR mutations in non-small-cell lung cancer: analysis of a large series of cases and development of a rapid and sensitive method for diagnostic screening with potential implications on pharmacologic treatment. J Clin Oncol 2005, 23:857-865.

27. Zhang J, Liang ZY, Zeng X, Wu SF, Gao J, Liu TH: Detection of epidermal growth factor receptor gene mutations in non-small cell lung cancers by real-time polymerase chain reaction using scorpion amplification refractory mutation system. Zhonghua Bing Li Xue Za Zhi 2008, 37(5):294-9, Chinese.

28. Bell DW, Lynch TJ, Haserlat SM, Harris PL, Okimoto RA, Brannigan BW, Sgroi DC, Muir B, Riemenschneider MJ, lacona RB, Krebs AD, Johnson DH, Giaccone G, Herbst RS, Manegold C, Fukuoka M, Kris MG, Baselga J, Ochs JS, Haber DA: Epidermal growth factor receptor mutations and gene amplification in non-small-cell lung cancer: molecular analysis of the IDEAL/INTACT gefitinib trials. J Clin Oncol 2005, 23:8081-8092.

29. Awaya H, Takeshima Y, Furonaka O, Kohno N, Inai K: Gene amplification and protein expression of EGFR and HER2 by chromogenic in situ hybridization and immunohistochemistry in atypical adenomatous hyperplasia and adenocarcinoma of the lung. J Clin Pathol 2005, 58:1076-80.
30. Kim YT, Kim TY, Lee DS, Park SJ, Park JY, Seo SJ, Choi HS, Kang HJ, Hahn S, Kang $\mathrm{CH}$, Sung SW, Kim JH: Molecular changes of epidermal growth factor receptor (EGFR) and Kras and their impact on the clinical outcomes in surgically resected adenocarcinoma of the lung. Lung Cancer 2008, 59:111-8.

31. Sasaki H, Shimizub S, Okudaa K, Kawanoa O, Yukiuea H, Yanoa M, Fujii Y: Epidermal growth factor receptor gene amplification in surgical resected Japanese lung cancer. lung cancer 2009, , 64: 295-300.

32. Soh J, Okumura N, Lockwood WW, Yamamoto H, Shigematsu H, Zhang W, Chari R, Shames DS, Tang X, MacAulay C, Varella-Garcia M, Vooder T, Wistuba II, Lam S, Brekken R, Toyooka S, Minna JD, Lam WL, Gazdar AF: Oncogene mutations, copy number gains and mutant allele specific imbalance (MASI) frequently occur together in tumor cells. PLoS One 2009, 4(10):e7464.

33. Yatabe $Y$, Takahashi T, Mitsudomi T: Epidermal growth factor receptor gene amplification is acquired in association with tumor progression of EGFR-mutated lung cancer. Cancer Res 2008, 68:2106-11.

34. Soh J, Toyooka S, Ichihara S, Asano H, Kobayashi N, Suehisa H, Otani H, Yamamoto H, Ichimura K, Kiura K, Gazdar AF, Date H: Sequential molecular changes during multistage pathogenesis of small peripheral adenocarcinomas of the lung. J Thorac Oncol 2008, 3:340-7.

35. Silvestri GA, Rivera MP: Targeted therapy for the treatment of advanced non-small cell lung cancer. A review of the epidermal growth factor receptor antagonists. Chest 2005, 128:3975-84.

36. Salomon DS, Brandt R, Ciardiello F, Normanno N: Epidermal growth factorrelated peptides and their receptors in human malignancies. Crit Rev Oncol Hematol 1995, 19:182-232.

37. Nakamura H, Kawasaki N, Taguchi M, Kabasawa K: Survival impact of epidermal growth factor receptor overexpression in patients with nonsmall cell lung cancer: a meta-analysis. Thorax 2006, 61:140-5.

38. Suzuki S, Dobashi Y, Sakurai H, Nishikawa K, Hanawa M, Ooi A: Protein overexpression and gene amplification of epidermal growth factor receptor in nonsmall cell lung carcinomas: an immunohistochemical and fluorescence in situ hybridization study. Cancer 2005, 103:1265-73.

39. Onn A, Correa AM, Gilcrease M, Isobe T, Massarelli E, Bucana CD, O'Reilly MS, Hong WK, Fidler IJ, Putnam JB, Herbst RS: Synchronous overexpression of epidermal growth factor receptor and HER2-neu protein is a predictor of pooroutcome in patients with stage I non-small cell lung cancer. Clin Cancer Res 2004, 10:136-43.

40. El-Zammar OA, Zhang S, Katzenstein AL: Comparison of FISH, PCR, and immunohistochemistry in assessing EGFR status in lung adenocarcinoma and correlation with clinicopathologic features. Diagn Mol Pathol 2009, 18(3):133-7.

\section{Pre-publication history}

The pre-publication history for this paper can be accessed here: http://www.biomedcentral.com/1471-2407/10/376/prepub

\section{doi:10.1186/1471-2407-10-376}

Cite this article as: Liang et al: Relationship between EGFR expression, copy number and mutation in lung adenocarcinomas. BMC Cancer 2010 10:376.

\section{Submit your next manuscript to BioMed Central and take full advantage of:}

- Convenient online submission

- Thorough peer review

- No space constraints or color figure charges

- Immediate publication on acceptance

- Inclusion in PubMed, CAS, Scopus and Google Scholar

- Research which is freely available for redistribution 